\title{
チクングニアウイルス感染蚊の体内における ウイルスの消長
}

\author{
山西 浩* 小西 英 二**

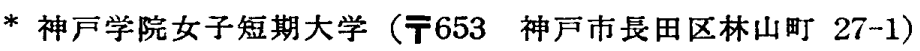 \\ ** 神戸大学医学部医動物学教室（二650 神戸市中央区楠町 7)
}

(受領：1987 年 8 月 8 日)

Studies on the development of chikungunya virus in the organs of infected mosquitoes

Hiroshi YAMANISHI and Eiji KONISHI

* Kobe Gakuin Women's Junior College, Nagata-ku, Kobe 653, Japan

** Department of Medical Zoology, Kobe University School of Medicine, Chuo-ku, Kobe 650, Japan

Key words: chikungunya virus, Aedes albopictus, midgut, hemolymph.

\section{はじめに}

蚊のチクングニアウイルス感受性は種によって異な る.一般的に Aedes albopictus や Ae. aegypti などの Aedes 属では感受性湻く, Culex fatigans, Cx. tritaeniorhynchus, Cx. poicilipes や $C x$. quinquefasciatus などの Culex 属では低い（山西ら，1983；McIntosh and Jupp, 1970; Jupp et al., 1981).また蚊のウ イルス伝搬能力は増幅動物に対する吸血咴好性の有無, 吸血活動の範囲あるいは個体群の大きさなどによって影 響されるが, 種のもつウイルス感受性は伝搬能力に及ぼ 寸最も基本的な要因である.

蚊の各器官におけるウイルスの消長は感受性決定の機 構を知るうえできわめて興味深い。したがってこの観点 での研究は多く, Culex tarsalis における西部馬脳炎ウ イルスの增殖 (Thomas, 1963), Culex pipiensにおけ る日本脳炎ウイルスの増殖 (LaMotte，1960), Culex annulirostris における MVE ウイルスの增殖 (McLean, 1953), Culex tritaeniorhynchus における日本脳 炎ウイルス（Doi，1970； Takahashi，1982）あるいは Aedes albopictus に扔けるデング熱ウイルスの增殖 Kuberski，1979）などの報告がある.
筆者らはヒトスジシマカにおけるチクングニアウイル スの感受性を調べている．ヒトスジシマカをはじめ種々 の蚊でのチクングニアウイルス感受性（山西ら，1983）, 高感受性のヒトスジシマカにおける系統間の感受性の比 較 (山西ら, 1984 ; 山西・小西, 1986; Konishi and Yamanishi，1986）について報告してきた.

これらの報告でチクングニアウイルスの蚊の感受性は 種や系統で著しく異なっていることが明らかとされた。 そこでウイルス感染後に器官でのウイルス消長を調べ， 種によってウイルス感受性が異なる原因を探った．この 結果若干の知見を得たので報告する.

\section{材料および方法}

蚊

今回の実験で使用した蚁はヒトスジシマカ（オアフ 系, 兵庫系, 们台 2 系), ネッタイシマカ (フィリピン 系）およびコガタアカイエカ(大阪系) であった。 それ ぞれの系統の由来は次のとおりりである.オアフ系は八ワ イ大学, Arbovirus Program, Rosen 研究室で累代飼育 されていた系統であり，1983 年 8 月より本研究室で累 代飼育している，兵庫系文実験の前に採集し 3 代累代飼 育した後実験に供した。仙台 2 系は長崎大学医学部医動 
物教室より 1985 年 5 月に分与された系統である。 ネッ タイシマカ,フィリピン系はフィリピン大学寄生虫研究 室より分与され，コガタアカイエカは大阪府公衆衛生研 究所医動物研究室より分与された系統である.これらの 蚊の飼育は約 $27^{\circ} \mathrm{C}$, 相対湿度 $70 \%$, 長日条件 (16 時間 明，8時間 暗）下で行った. 幼虫は 1,000 個体を $30 \times$ $50 \mathrm{~cm}$ のバット容器に入れマウス 用固形飼料の粉末を 与えて飼育した. 成虫は $30 \times 30 \times 30 \mathrm{~cm}$ の布ケージに 移しておよそ $0.7 \%$ の砂糖水を与えて飼育した。

\section{ウイルス}

感染実験に使用したチクングニアウイルスは, 分離後 乳飲みマウス脳で 174 代継代したもので大阪大学微生物 病研究所より分与されたアフリカ株である.この株を BHK-21 単層培養細胞で 4 代継代したものを使用した.

\section{感染方法}

約 $50^{\circ} \mathrm{C}$ の湯を入れた $100 \mathrm{ml}$ の三角フラスコに脱脂 綿を固定し，その脱脂綿にウイルス混入血液を約 $10 \mathrm{ml}$ しみこませ, ケージに入れて蚊に吸わせた. ウイルス混 入血液はおよそ $1.3 \times 10^{9} \mathrm{PFU} / \mathrm{ml}$ の感染培養液 $1 \mathrm{ml}$ めん羊脱纎維血 $20 \mathrm{ml}$ と混合したものである. ウイルス を経口的に感染させたときの蚊の日齢は羽化後 $6 \sim 8$ 日 であった. ウイルス混入血液を吸血した蚊は別のケージ に移して飼育した。

\section{ウイルスの測定方法}

コガタアカイエカ, ネッタイシマカ, ヒトスジシマカ での感染後の体内でのウイルスの消長を比較するため, 頭胸部，中腸および中腸をとり除いた腹部の 3 部分にわ けて感染後のウイルス量を測定した．ただし吸血直後は 中腸の摘出が困難であったので，ウイルスの測定は頭胸 部と腹部の 2 部分に分けて行った.

チクングニアウイルス感受性の異なるオアフ系と兵庫
系でウイルス感染後, 脳, 唾液腺, 中腸, 体液でウイル ス量を経日的に調べ比較した．さらにオアフ系と仙台 2 系でも体液でのウイルス量の変動を比較した．体液は PBS で腹部を洗浄し，洗浄後の PBS のウイルス量を 測定した。 ウイルス量の測定方法は山西ら（1984）など と同様である.

\section{結 果}

実験 1 感染後のコガタアカイエカ，ネッタイシマ カ, ヒトスジシマカ（兵庫系，オアフ系）の頭胸部, 中腸，腹部におけるチクングニアウイルスの变動 チクングニアウイルス感染後の頭胸部, 中腸, 中腸を 除いた腹部のウイルス量を Figs. 1〜 4 に示した.コガ タアカイエカではチクングニアウイルスは增殖しないの で（山西ら，1983）血液が完全に消化した感染後 4 日め までウイルス量を測定した。感染直後のウイルス量は $10^{4.5} \sim 10^{4.9} \mathrm{PFU}$ であった. 感染直後に測定した 5 個体 のうち 2 個体で頭胸部に少量のウイルスが検出された. これは血液が消化器官を通過したとき, 頭胸部の消化器 官の内壁に付着していたものであろう. 感染後 1 日めに は中腸にだけ感染直後よりやや低い值のウイルスが認め られ，感染後 2 日めと 3 日めには頭胸部，中腸，腹部の いずれの部位からもウイルスは検出されなかった。

ネッタイシマカの感染直後の中腸におけるウイルス量 は 104.8 10 $0^{5.2} \mathrm{PFU}$ であったが，頭胸部にも少量のウ イルスが検出された. 感染後 1 日めにはやはり中腸にの みウイルスが認められた．与えたウイルス量が異なって いたためか感染直後のウイルス量はやや多かったが, 感 染後 1 日めにはコガタアカイエカとほぼ同じ量になっ た. 2 日め以降は一部の個体の中腸にのみウイルスが検 出された。 2 日めから14日めにかけて調べた 25 個体の

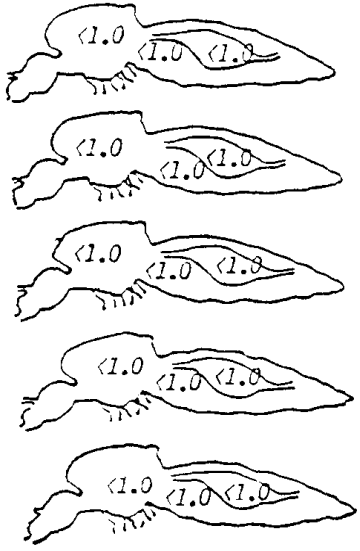

2 days after feeding

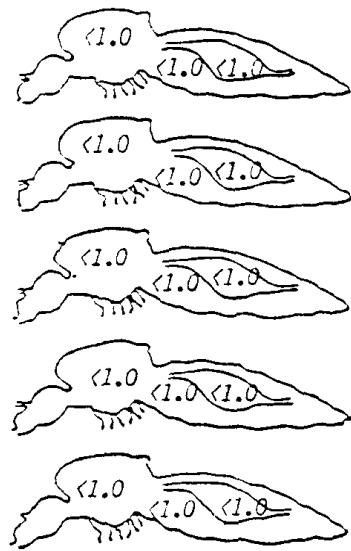

3 days after feoding

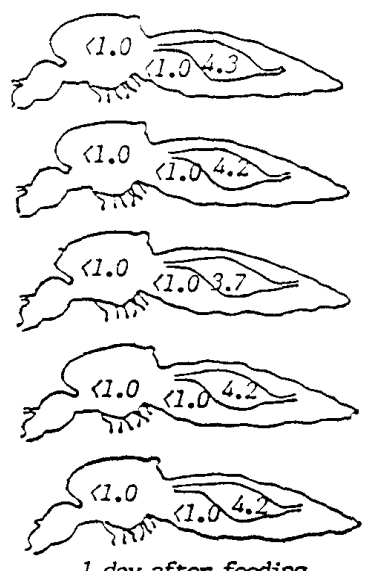

1 day after feoding

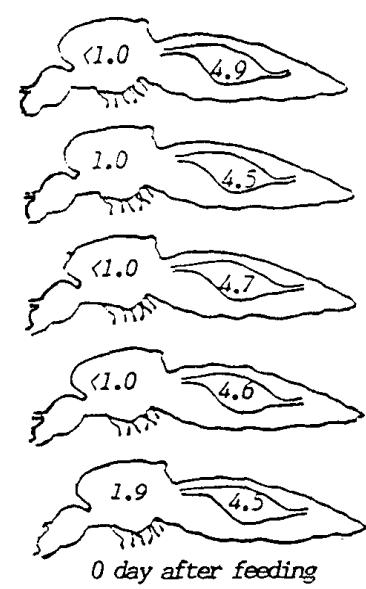

Fig. 1 Chikungunya virus titer (log PFU) in head/thorax, abdomen (without midgut) and midgut of individual Culex tritaeniorhynchus mosquitoes after oral infection. 


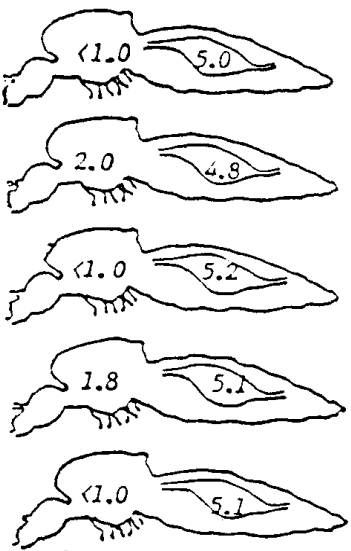

0 day after feeding
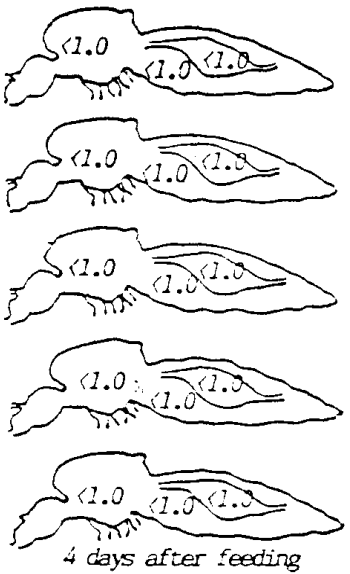

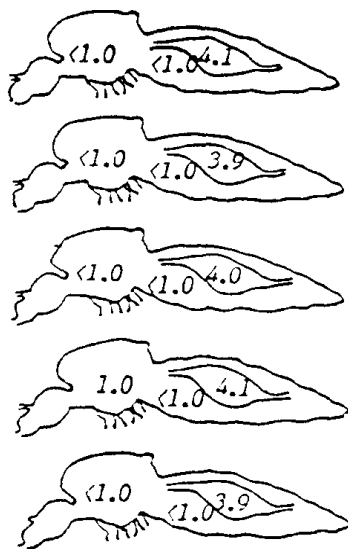

1 dey after feuding
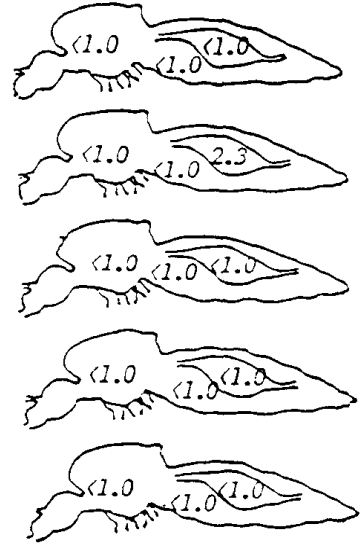

2 days after feeding
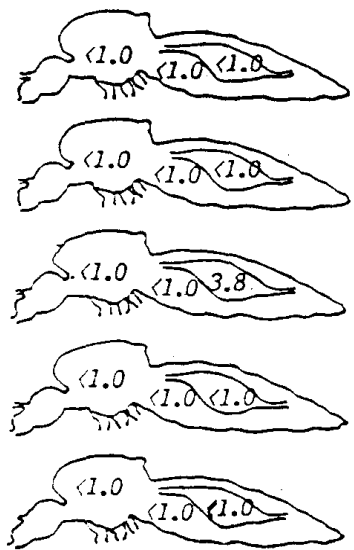

3 days after feeding

Fig. 2 Chikungunya virus titer ( $\log$ PFU) in head/thorax, abdomen (without midgut) and midgut of individual Aedes aegypti mosquitoes after oral infection.

うち中腸でウイルスの認められた個体の割合は12.0\% であった。

ヒトスジシマカ兵庫系では感染直後 は中腸で $10^{4.3}$ $10^{4.6} \mathrm{PFU}$ であり，頭胸部で 2 個体にウイルスが検出さ れた. 感染後 1 日めにはやはり中腸に102.8〜104.0 PFU のウイルスが検出されたが，2 日め以降のウイルスの消 長は前の 2 種とは著しく異なっていた．感染後 2 日めに 1 個体で頭胸部, 中腸, 腹部のすべての部分からウイル スが検出され，頭胸部でのウイルス量は感染時のウイル ス量上ほぼ同じであった。ささらに3日めにも $10^{2.1} \mathrm{PFU}$ と量はやや低いが頭胸部からも検出された。しかし2〜 4 日めの感染初期に中腸でウイルスの検出されなかった 個体も多く，15 個体のうち8 個体とおよそ半数を占め た. しかし感染後 7 日め，14日めに 10 個体のうち 9 個体からウイルスが検出された. しかし頭胸部や腹部 (中腸学取り除いた残部) からはウイルスは検出されな かった。

オアフ系ヒトスジシマカでは感染直後は中腸で104.3〜 $10^{4.8} \mathrm{PFU}$ と兵庫系や他の種とほほ同じであったが，頭
胸部でウイルスの検出された個体が 4 個体と多かった。 感染後 1 日めにはウイルスは中腸だけに想めら扎，兵庫 系あるいは他の種とまったく同じ傾向であった，感染後 $2 \sim 4$ 日めは全個体の中腸でウイルスが検出された。中 腸を取り除いた腹部では 2 日め，3 日めに 1 個体ずつ, 4 日めに4個体にウイルスが検出された，頭胸部では感 染後 3 日めに 1 個体，4日めに 3 個体にウイルスが検出 された。 4 日めには $10^{5.4}$ PFU と高いウイルス量を示 す個体も観察された７日め，14日にはすべての部分 でウイルスが検出された個体が 10 個体のうち6個体あ った。ウイルス量は頭胸部でもっとも高く, 最高で $10^{7.3}$ $\mathrm{PFU}$ であった，ウイルスの動问を兵庫系と比較する 上, 感染初期の 2 4 日めの感染率，7日め以降の增殖 ウイルス量に違いがみられた。

実験 2 ヒトスジシマカ兵庫系とオアフ系の脳, 唾液 腺, 中腸前部および後部におけるウイルスの消長

ヒトスジシマカオアフ系でウイルス感染後 3 日め, 7 日め，14 日めに脳，唾液腺，中腸前部および後部でウイ ルス量を測定した。 また兵庫系で 14 日めに同様に測定 


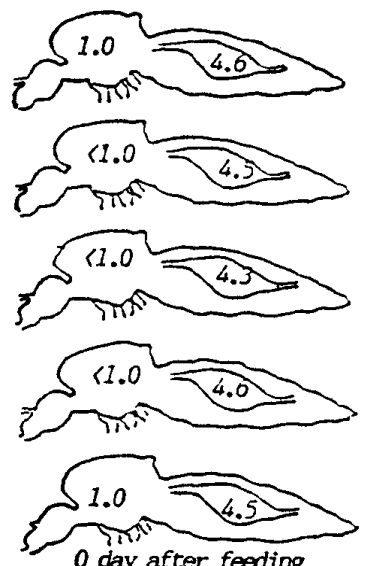

0 day after feoding

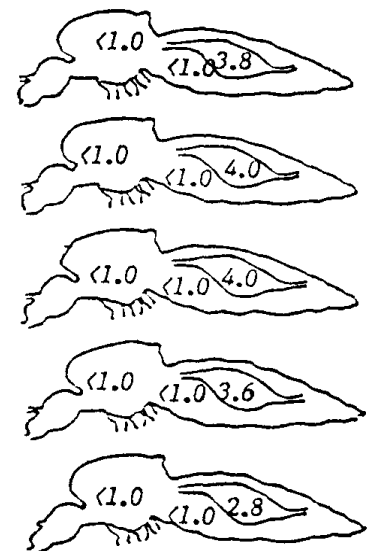

1 day after feding
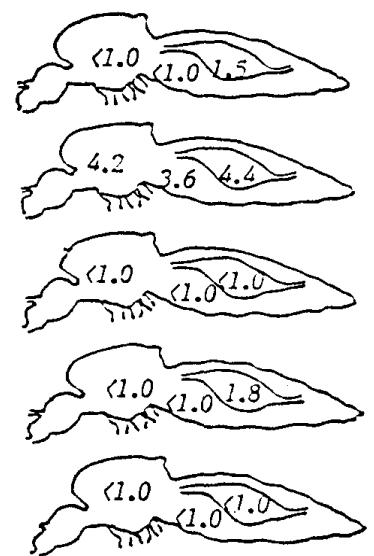

2 days after feeding

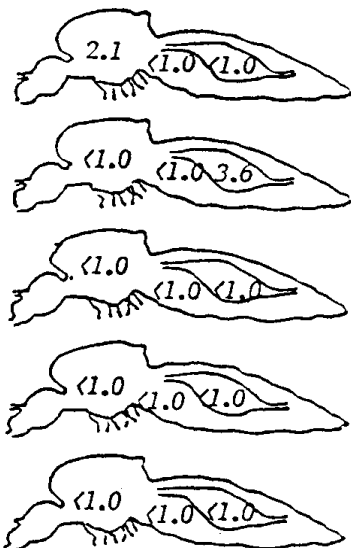

3 days after feeding
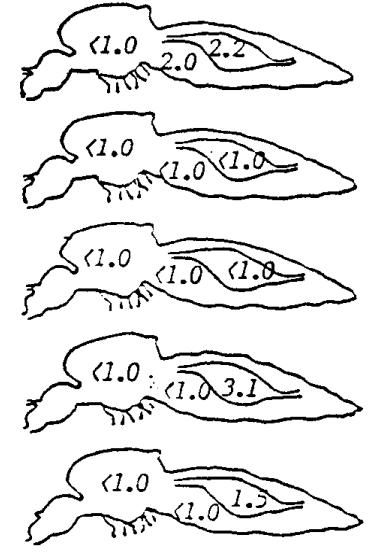

4 days after feeding
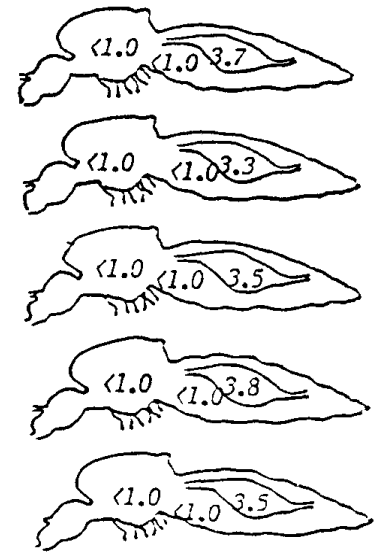

7 days after feeding

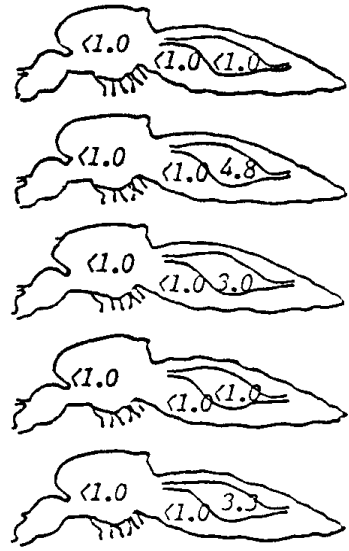

14 days after feeding

Fig. 3 Chikungunya virus titer ( $\log$ PFU) in head/thorax, abdomen (without midgut) and midgut of individual Aedes albopictus (Hyogo strain) mosquitoes after oral infection.

してオアフ系と比較した (Table 1).オアフ系では感染 後 3 日めにはすべての個体の中腸後部にウイルスが検出 され，また 2 個体には中腸前部にもウイルスが認められ た. 7 日めにはまったくウイルスの検出されない個体が 2 個体あったが，脳，唾液腺の両方に高いウイルス量を 認めた個体が 1 個体あった. 14 日めには 4 個体に全器 官で，また 2 個体に中腸のみにウイルスを検出した。い っぽう，兵庫系の感染後 14 日めには 7 個体のうち 6 個 体で中腸にウイルスが認められた。実験 1 と同様兵庫系 とオアフ采における蚊体内でのウイルスの消長の違いが 示された。

\section{実験 3 ヘモリンフにおけるウイルスの出現}

実験 1 ，実験 2 において，中腸におけるウイルスの増 殖およびそこからのウイルスの移動が，蚊のウイルス感 受性を決定しているように思われたので，中腸から他の 器官へのウイルスの移動に扔けるへモリンフの役割に注 目し，ヒトスジシマカの各系統でウイルスの変動を比較 した，感染後 7 日めに兵庫系上オアフ系で脳，へモリン
フ, 中腸でウイルス量を比較して Table 2 にまとめた. オアフ系では 7 日めには測定した 8 個体のすべての中腸 にウイルスが認められたが，そのうち 6 個体がへモリン フから，また 3 個体が唾液腺からウイルスが検出され た. 兵庫系では全個体で中腸にウイルスが 検出された が，へモリンフでは 3 個体, 唾液腺で 1 個体であった.

兵庫系よりやや感受性の高い仙台 2 系とオアフ系で中 腸と体液のウイルス量を比較した（Fig. 5)。オアフ系 では感染直後から1日めにかけて中腸でのウイルス量は $10^{2.0} \sim 10^{3.0} \mathrm{PFU}$ とやや低かったが，2 日めより $10^{3}$ 台 となりウイルスが維持されていた．14日めにはおよそ $10^{4.0} \mathrm{PFU}$ に達した. へモリンフでのウイルスは感染後 1 日めに $10^{2.0} \mathrm{PFU}$ 程度で検出されたが, 感染後の日 数がたつにつれてウイルスの検出されない個体もみられ た。検出された個体ではウイルス量は多くなり，6日め には104.2 PFU，14 日めには $10^{5.5} \mathrm{PFU}$ となった。

仙台 2 系では中腸では感染直後より 7 日めまでおよそ $10^{3.0} \mathrm{PFU}$ であり, 14 日めには $10^{5.0} \mathrm{PFU}$ と高いウイ 

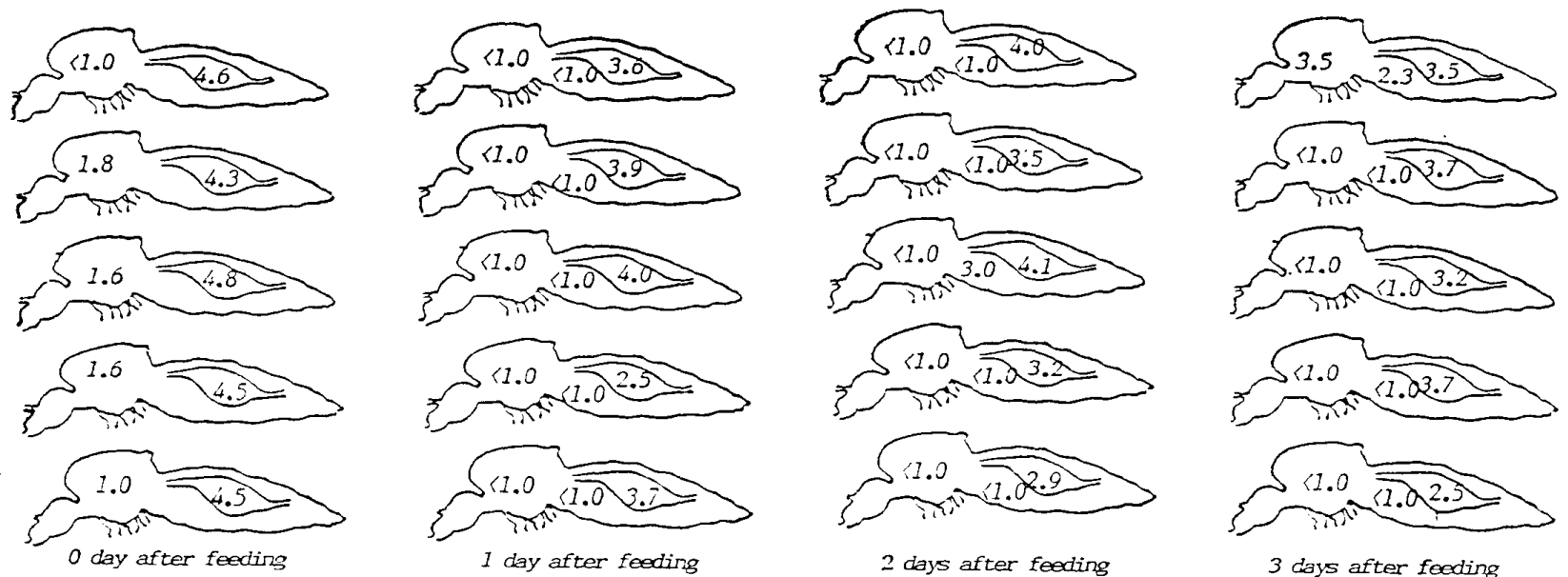

3 days after foeding
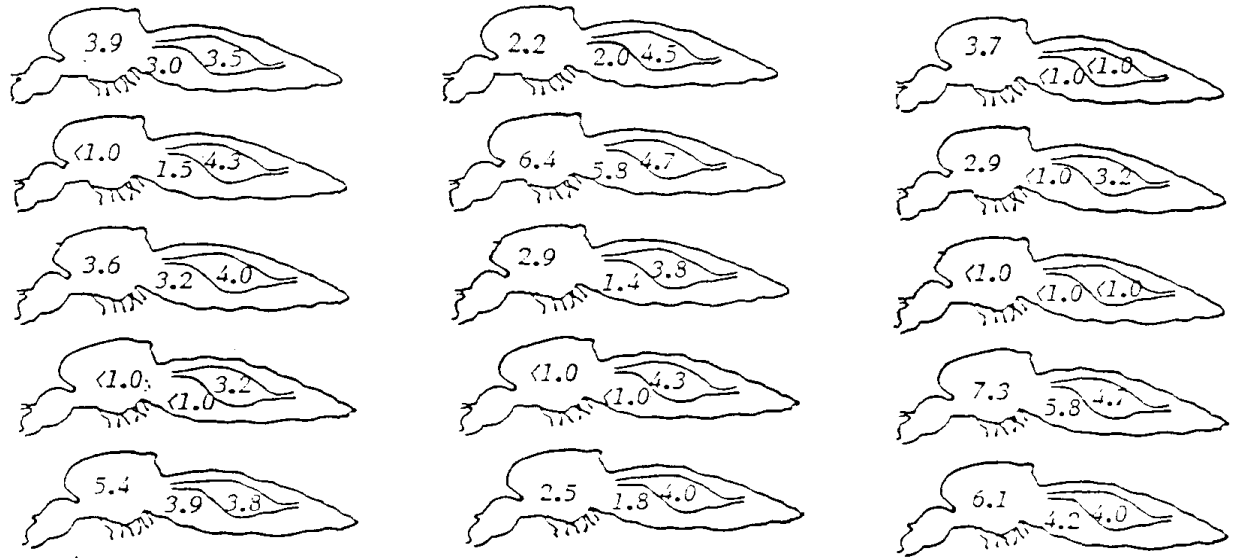

7 days after foeding

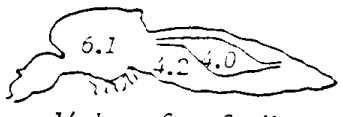

14 days after foeding

Fig. 4 Chikungunya virus titer ( $\log \mathrm{PFU}$ ) in head/thorax, abdomen (without midgut) and midgut of individual Aedes albopictus (Oahu strain) mosquitoes after oral infection.

ルス量の個体が観察された.ヘモリンフでは感染直後は $10^{1.0} \sim 10^{2.3}$ PFU であった, 2〜 7 日めにかけて検出さ れない個体が多かった，14 日めには 103.0〜10 とウイルス量の多い個体もみられた.オアフ系と仙台 2 系のウイルス消長を比較すると中腸ではほぼ同じ傾向が みられたが，へモリンフではオアフ系ではウイルスが維 持されている個体が多く, 仙台 2 系ではウイルスの検出 されない個体が多いところに系統間の違いが認的られ た。

感染血液を吸った直後の蚊の中腸のウイルス量は $10^{4.3}$ 104.8 PFU であったが（Fig. 4)，この実験では $10^{1.8} \sim 10^{2.4} \mathrm{PFU}$ と低かった。これは中腸の洗浄の結果 であるが，早い時期にウイルスが中腸壁に吸着すること が示唆された。

\section{考察}

チクングニアウイルスに感受性のまったくないコガタ アカイエカ, 感受性の非常に低いネッタイシマカ, 感受
性のあるヒトスジシマカ兵庫系, ヒトスジシマカオアフ 系における経口感染後の中腸, 腹腔, 頭胸部でのウイル ス消長を比較した，中腸での血液の消化は吸血後 2 日め にほぼ完了するが (Konishi and Yamanishi 1986), ウ イルス感受性がまったくないコガタアカイエカの場合に は血液の消化とともにウイルスが完全に消失していた。 また低い感受性を示すネッタイシマカでは初期の状態は コガタアカイエカと同に゙傾向がみられたが，2 日め以降 に一部の個体の中腸でウイルスが保持されていた，ウイ ルス感受性の高いヒトスジシマカ兵庫系やオアフ系では 感染後中腸でのウイルス保持が継続され，系統によって 中腸以降のウイルスの動向が異なっていた。このように チクングニアウイルスの感受性は血液消化に伴って中腸 で決定されるようである。

この中腸での感受性決定は他のウイルスでも報告され ている，ウイルスに感染した後の蚊の器官でのウイルス の移行は监光抗体法を用いて Doi (1970) がコガタアカ イエカで日本脳炎ウイルス，Kuberski（1979）がヒトス 
Table 1 Virus titer in organs of Aedes albopictus at intervals after oral infection.

\begin{tabular}{|c|c|c|c|c|c|}
\hline \multicolumn{2}{|c|}{$\begin{array}{l}\text { Specimen } \\
\text { No. }\end{array}$} & Brain & $\begin{array}{l}\text { Salivary } \\
\text { glands }\end{array}$ & $\begin{array}{c}\text { Anterior } \\
\text { of } \\
\text { midgut }\end{array}$ & $\begin{array}{c}\text { Posterior } \\
\text { of } \\
\text { midgut }\end{array}$ \\
\hline \multicolumn{6}{|c|}{ Oahu strain } \\
\hline \multirow{7}{*}{$\begin{array}{l}\text { 3rd } \\
\text { day }\end{array}$} & 1 & $<1.00$ & $<1.00$ & 3.11 & 4.38 \\
\hline & 2 & $<1.00$ & $<1.00$ & $<1.00$ & 2.78 \\
\hline & 3 & $<1.00$ & $<1.00$ & $<1.00$ & 3.60 \\
\hline & 4 & $<1.00$ & $<1.00$ & $<1.00$ & 2.75 \\
\hline & 5 & $<1.00$ & $<1.00$ & 1.70 & 3.64 \\
\hline & 6 & $<1.00$ & $<1.00$ & $<1.00$ & 3.72 \\
\hline & 7 & $<1.00$ & $<1.00$ & $<1.00$ & 2.04 \\
\hline \multirow{7}{*}{$\begin{array}{l}\text { 7th } \\
\text { day }\end{array}$} & 1 & $<1.00$ & $<1.00$ & $<1.00$ & $<1.00$ \\
\hline & 2 & $<1.00$ & $<1.00$ & $<1.00$ & $<1.00$ \\
\hline & 3 & $<1.00$ & $<1.00$ & 2.36 & 3.71 \\
\hline & 4 & 5.15 & 5.57 & 3.89 & 3.90 \\
\hline & 5 & $<1.00$ & $<1.00$ & $<1.00$ & 2.41 \\
\hline & 6 & $<1.00$ & $<1.00$ & $<1.00$ & 3.30 \\
\hline & 7 & $<1.00$ & $<1.00$ & - & 3.49 \\
\hline \multirow{7}{*}{$\begin{array}{l}14 \text { th } \\
\text { day }\end{array}$} & 1 & 3.69 & 3.64 & 3.96 & 3.34 \\
\hline & 2 & $<1.00$ & $<1.00$ & $<1.00$ & 3.14 \\
\hline & 3 & $<1.00$ & $<1.00$ & $<1.00$ & 3.59 \\
\hline & 4 & $<1.00$ & $<1.00$ & - & 3.84 \\
\hline & 5 & 4.00 & 5.36 & 5.73 & 5.85 \\
\hline & 6 & 5.11 & 5.30 & 3.32 & 5.47 \\
\hline & 7 & 3.51 & 5.27 & 5.67 & 5.60 \\
\hline \multicolumn{6}{|c|}{ Hyogo strain } \\
\hline \multirow{7}{*}{$\begin{array}{l}\text { 14th } \\
\text { day }\end{array}$} & 1 & $<1.00$ & $<1.00$ & $<1.00$ & $<1.00$ \\
\hline & 2 & $<1.00$ & $<1.00$ & $<1.00$ & 3.88 \\
\hline & 3 & $<1.00$ & $<1.00$ & $<1.00$ & 3.45 \\
\hline & 4 & $<1.00$ & $<1.00$ & $<1.00$ & 3.38 \\
\hline & 5 & 1.85 & $<1.00$ & 3.00 & 3.32 \\
\hline & 6 & $<1.00$ & $<1.00$ & $<1.00$ & 3.62 \\
\hline & 7 & $<1.00$ & 1.00 & 2.67 & 3.70 \\
\hline
\end{tabular}

ジシマカでデング 2 型ウイルスを報告している。 また LaMotte（1960）はネッタイイエカに日本脳炎ウイルス を感染させ 10 週間にわたって器官別にウイルス量を 測 定している.

これらの報告ではチクングニアウイルスの場合む含め て感染後の蚊器官間のウイルスの移行日数は異なるが, ウイルスの初期感染はいずれも中腸後部の表皮細胞に始 まることが示唆されている。しかしウイルスの増殖が中 腸で決定される機構については明らかでない，

中腸でのウイルスの増殖または不活化に影響を及ぼす 要因としてまず中腸上皮紐胞のウイルスに対するレセプ
Table 2 Virus titer in salivary glands, hemolymph and midgut of Aedes albopictus on 7 th day after oral infection.

\begin{tabular}{|c|c|c|c|}
\hline $\begin{array}{c}\text { Specimen } \\
\text { No. }\end{array}$ & $\begin{array}{l}\text { Salivary } \\
\text { glands }\end{array}$ & Hemolymph & Midgut \\
\hline \multicolumn{4}{|c|}{ Oahu strain } \\
\hline 1 & $<1.00$ & $<1.00$ & 3.08 \\
\hline 2 & $<1.00$ & 3.38 & 4.81 \\
\hline 3 & $<1.00$ & $<1.00$ & 3.69 \\
\hline 4 & 4.64 & 4.48 & 4.11 \\
\hline 5 & $<1.00$ & 3.11 & 4.73 \\
\hline 6 & 5.00 & 4.08 & 4.68 \\
\hline 7 & 2.49 & 3.43 & 4.41 \\
\hline 8 & $<1.00$ & 2.80 & 4.55 \\
\hline \multicolumn{4}{|c|}{ Hyogo strain } \\
\hline 1 & $<1.00$ & 4.62 & 3.38 \\
\hline 2 & $<1.00$ & $<1.00$ & 4.60 \\
\hline 3 & $<1.00$ & $<1.00$ & 3.95 \\
\hline 4 & 3.89 & 5.08 & 3.23 \\
\hline 5 & $<1.00$ & $<1.00$ & 3.48 \\
\hline 6 & $<1.00$ & 3.88 & 3.60 \\
\hline 7 & $<1.00$ & $<1.00$ & 3.98 \\
\hline
\end{tabular}

タ一の有無が考えられる．それ以外に囲食膜の作用，イ ンターフェロンないし類似のウイルス増殖抑制物質の産 生（高橋ら，1973）などが考えられる.

培養細胞におけるチクングニアウイルスの成熟過程を みるとウイルス前駆体の細胞翼膜下人の出現, 前駆体の 細胞膜の突き上げとウイルス envelope の形成, ウイル ス感染によって修旍された細胞膜による前駆体のつつみ こみを経て成熟するという（松村，1975).このような ウイルス成熟過程で中腸の生理的環境が影響を及ぼすの であろう。

ウイルス感受性の定量的表現として $5 \%$ 程度あるいは 50 \%を感染せしめるウイルス量としての minimum infective dose や $50 \%$ infective dose など種々の方法が 使われている，蚊の感受性をみるとき中腸でのウイルス の動態は重要である. したがって中腸で血液の消化が完 了した時期における腸内のウイルス量あるいは感染率は 感受性の定量的な值を示すと思われる. 実験 1 で血液が 消化される 感染後 $2 \sim 3$ 日めのウイルス感染率で示す と, コガタアカイエカ $0 \%$ ， ネッタイシマカ $10 \%$, ヒ トスジシマカ兵庫系 $40 \%$ ，同オアフ系では $100 \%$ とな り，それぞれの種あるいは系統の感受性の違いが表され ている.

ウイルス感受性のあるヒトスジシマカの系統間でも器 


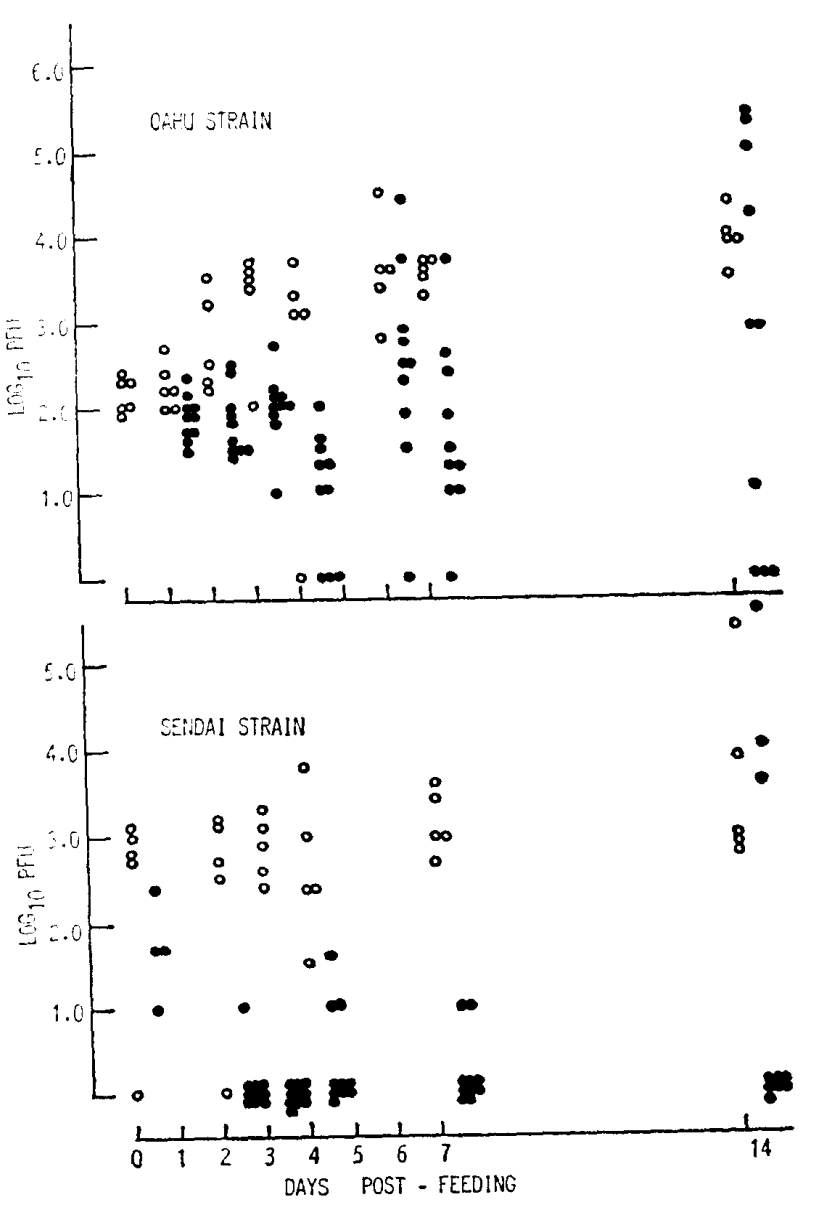

Fig. 5 Virus titer (log PFU) in hemolymph (๑) and midgut (O) of Aedes albopictus (Oahu and Sendai 2) strains at intervals after infection.

官でのウイルス移行は異なっていた，オアフ系，兵庫 系, 仙台 2 系のいずれの系統でも感染後中腸でウイルス がみられた，どの系統でも中腸でのウイルス量はおよそ $10^{4.0}$ 台を越えなかった。しかし脳や睡液腺など他の器 官への感染はオアフ系で著しかった。 これはへモリンフ の中のウイルスにもみられ, 中腸以降のウイルスの動態 に興味がもたれた，兵庫系などではウイルスを中腸にと どめておく機楧があるのかもしれない。

$$
\text { まとめ }
$$

コガタアカイエカ, ネッタイシマカ, ヒトスジシマカ 兵庫系, ヒトスジシマカオアフ系でチクングニアウイル ス感染後の体内でのウイルス消長を調べた，中腸，腹部 (中腸を取り除いた残部）と頭胸部の 3 部分に分けて, 感染後のウイルス量を測定した. コガタアカイエカでは 感染後 2 日めに中腸でウイルスは消隇した. ネッタイシ マカでは感染後 2 日めに中腸で消減した個体が多かった が，一部の個体では中腸でウイルスが認められた。 ヒト スジシマカ兵庫系では中腸に多くの個体でウイルスが存
在していたが，感染後日数を経ても他の部分ではほとん ど検出されなかった. ヒトスジシマカオアフ系では中腸 をはじめ腹部，頭䐧部でもウイルスがみられた.このよ うに中腸におけるウイルスの動態は感受性決定に重要で あり，ウイルス感受性の差を示す方法として血液消化時 のウイルス保有率で表現することができよう．また感受 性の高いヒトスジシマカでは系統によって器官間のウイ ルス移行の差がみられた。

\section{引用文献}

Doi, R. (1970): Studies on the mode of development of Japanese encephalitis virus in some groups of mosquitoes by the fluorescent antibody technique. Jpn. J. Exp. Med., 40 : 101-115.

Jupp, P. G., B. M. McIntosh, I. Dos Santos and P. de Moor (1981): Laboratory vector studies on six mosquitoes and one tick species with chikungunya virus. Trans. $R$. Soc. Trop. Med. Hyg., 20 : 642-645.

Konishi, E. and H. Yamanishi (1986): Titer distribution analysis of chikungunya virus in Aedes albopictus. J. Med. Entomol., 23 : 9298.

Kuberski, T. (1979) : Fluorescent antibody studies on the development of Dengue- 2 virus in Aedes albopictus. J. Med. Entomol., 16 : 343349.

LaMotte, L. C. (1960): Japanese B encephalitis virus in the organs of infected mosquitoes. Am. J. Hyg., 72 : 73-87.

松村武男（1975）：培養細胞におけるウイルス成熟 機構一特にトガ（Toga）ウイルスを中心上して 一. 組織培養, 1:168-175.

McIntosh, B. M. and P. G. Jupp (1970): Attempts to transmit chikungunya virus with six species of mosquito. J. Med. Entomol., $7: 615$ 618.

McLean, D. M. (1953): Transmission of Murray valley encephalitis virus by mosquitoes. Aust. J. Exp. Biol., 31: 481-490.

Takahashi, M. (1982) : Differential transmission efficiency for Japanese encephalitis virus among colonized strains of Culex tritaeniorhynchus. Jpn. J. Sanit. Zool., $33: 325-333$.

高橋三雄, 石井 孝, 唐牛良明 (1973)：日本脳炎 ウイルスの vector.ウイルス, $23: 173-183$.

Thomas, L. A. (1963): Distribution of the virus of Western equine encephalitis in the mosquito vector, Culex tarsalis. Am. J. Hyg., 78 : 150-165.

山西 浩，小西英二 (1986)：ヒトスジシマカにお けるチクングニアウイルス量の蛍光抗体法による 测定の試み。衛生動物, $37: 371-375$. 
山西 浩, 小西英二, 松村武男 (1984)：2 系統の ヒトスジシマカにおけるチクングニアウイルス感 受性の比較. 衛生動物, $35: 361-365$.

山西 浩, 小西英二, 沢山俊子, 松村武男 (1983):

数種の蚊のチクングニアウイルス感受性につい

て. 衛生動物, 34:229-233.

\section{Summary}

Chikungunya (CHIK) virus concentrations in the head/thorax, midgut and other abdominal parts were measured to compare virus multiplication in the mosquito Culex tritaeniorhynchus, Aedes aegypti and two strains of Ae. albopictus (Hyogo and Oahu strain) by plaque assay with BHK 21 cells. In Cx. tritaeniorhynchus, CHIK virus disappeared from the midgut by the 2nd days after feeding. In Ae. aegypti, CHIK virus was observed in $12 \%$ of the midgut for 2 weeks after infection. In the Hyogo strain of Ae. albopictus, CHIK virus was observed in $60 \%$ of the midgut for 2 weeks. CHIK virus was not detected in the other tissues on the 4 th day after feeding. In the Oahu strain of Ae. albopictus, all the midgut specimens were positive for CHIK virus by the 7 th day after infection. On the 7 th and the 14 th day after infection, CHIK virus was detected in the other parts than the midgut.

Multiplication of CHIK virus in the brain, salivary glands, anterior'midgut, posterior midgut and hemolymph was compared between the Oahu and the Hyogo strains of Ae. albopictus. Virus titers in their organs were clearly different between the two strains in parallel with the difference in susceptibility. Multiplication of CHIK virus in hemolymph was considered to play a role in disseminating the virus released from midgut cells to the other organs of mosquitoes. 